\title{
Determinants of tax morale in Spain and Turkey: an empirical analysis
}

\author{
Cevat Bilgin, Cukurova University, Turkey
}

\begin{abstract}
Tax morale is defined as the intrinsic motivation to pay taxes, and is closely related to tax compliance. Determinants of tax morale need to be investigated for a more comprehensive understanding of tax compliance. In this paper, determinants of tax morale in Turkey and Spain are analysed on the basis of World Values Survey data. Firstly, descriptive statistics of the variables used in the models are provided. Since tax morale is an ordered categorical dependent variable, ordered probit models are estimated separately for Turkey and Spain to derive the relations between tax morale and relevant variables. Marginal effects are computed since the coefficients of the models cannot be interpreted because of the nonlinearity of the estimated models. The marginal effects related to the top level of tax morale category are presented. The independent variables are combined by demographic factors, employment categories, economic status of the respondents and social capital variables. The findings from the estimated model suggest that social capital variables and some of the demographic factors have important effects on tax morale in Turkey. Confidence variables have positive effects; if taxpayers feel confidence in political entities they are willing to pay taxes. Religion and national pride affect tax morale positively. On the other hand, the results are different for Spain; social capital variables do not have effects on tax morale. Specifically, confidence variables are found to be statistically insignificant. Age, education level and the income level have significant effects on tax morale in Spain.
\end{abstract}

\section{JEL classification}

H26; C51; C52.

\section{Keywords}

Tax morale; tax evasion; ordered probit. 


\section{Introduction}

Tax evasion is an important issue in almost all countries. While some taxpayers seek the ways of evasion, the others are not eager to evade. Tax morale is, to large extent, to do with the physiological background of these behaviours. Arguably, tax morale is concerned with why people do not evade. There has been much in common between tax morale and tax compliance. Tax compliance is an observable action; that is most people pay their taxes. Tax compliance is not only a function of tax ratios and probability of detection, but also a function of an individual's willingness to comply with and to evade. As Torgler (2007) pointed out, level of tax compliance is relatively high when tax morale is high; therefore tax morale is needed for providing on an account of the puzzle of tax compliance.

Determinants of tax morale need to be investigated for a much more comprehensive understanding of tax compliance. Nevertheless, there is a limited work on the issue in the existing literature (Torgler, 2004, 239). As Feld and Frey $(2002,88)$ suggest:

\footnotetext{
Most studies treat 'tax morale' as a black box without discussing or even considering how it might arise or how it might be maintained. It is usually perceived as being part of the metapreferences of taxpayers and used as the residuum in the analysis capturing unknown influences to tax evasion. The more interesting question then is which factors shape the emergence and maintenance of tax morale.
}

Indeed, few scholars have conducted research on tax morale in detail.

By definition, tax morale is an intrinsic motivation to pay taxes (Torgler, 2007, 4). Morality could be defined as an individual's internalisation of such concepts and legal rules to perform his or her social duties in a proper way. Hence, individuals' general attitude (or tax mentality) towards taxation and specific liabilities imposed by the related legislation is substantial to the debate. From this perspective, tax morale is largely framed in the general concept of tax mentality (Schmölders, 1976: 107).

For Torgler (2004), tax morale measures taxpayers' attitudes while tax evasion measures taxpayers' behaviours. In other words, tax morale is not an outcome variable, like tax evasion. Tax morale can, hence, be defined as a moral obligation of paying taxes; it is, in turn a belief of contributing to society by paying taxes.

Tax compliance and tax morale are affected by social and physiological factors. Therefore increasing the level of tax morale and tax compliance depends heavily on these factors. Legal infrastructure and state enforcement power, to some extent, raise the level of tax compliance. Social and physiological factors are still decisive factors to change tax morale. Social capital evokes individuals' economic and cultural capitals; perceptions on income distribution, on fairness in society, trust in others and institutions, and confidence in government and in government policies are some of examples of social capital variables.

Socio-demographic variables affect tax morale substantially. The first of them is the variable of age. Relatively older people are more vulnerable to threats of sanctions, suggested by the relevant studies. As Torgler (2007) points out, the reason is that people are attaining new social characteristics, such as property, status, dependency on others' behaviours as they get older. Therefore the potential costs of penal sanctions for older people seem to be relatively greater. In consequence, there might be a significant relation between tax morale and age. Furthermore, socio-physiological studies reveal that females are more compliant and less selfish than males. Nevertheless, it should be noted that the traditional role of females is substantially different from the role of females in a modern society. Moreover, females have more risk-averse behaviours than males have. Marital status is another individualistic variable that might affect tax morale. The more social ties the individual has, the more restrictions imposed on her or his behaviour. Thus married individuals are more prone to exhibit legal behaviours. 
For Torgler (2007), employment status is another important factor for tax morale. It might be argued that self-employed persons have lower tax morale than full-time and part-time employees. This might be explained by the fact that the selfemployed have more opportunities to evade tax. The relation between education level and tax morale is not clear. According to Torgler and Schneider (2006), educated taxpayers are thought to have more information about tax regulations and fiscal relations. Besides, they might be aware of civil services provided by state, and so they might have high level of tax compliance. On the other hand, they seemingly have knowledge of public corruption and thereby they might have critical perception on how tax revenues are used by government. Moreover, they know a lot about the opportunities to evade tax. As a result of these factors, it is assumed that they have a low level of tax morale. Consequently, there have been different kinds of relations between education level and tax morale. The relation between level of income and tax morale is a bit complicated and thus depends on some conditions. When people are not satisfied with their financial situation, they might tend to be evader. If a taxpayer feels a gap between his current and desired financial situation, he would be unwilling to pay taxes. Moreover, they would be more reluctant to pay taxes if they feel they have less when they compare their income and their wealth with others'. On the contrary, Duch, Palmer and Anderson (2000) claim that people who have low level of income are willing to pay taxes since they think they have benefit from public goods and services more than people having high level of income have benefit from. Wealthy people, on the other hand, would be less willingly pay taxes by the perception of having benefited from public goods and services less than others.

Taxpayer confidence in parliament, government, justice system, tax administration has a valuable relation with tax morale. If the level of this confidence is high enough, individuals' loyalty to public administration would increase and so they would be more willingly to pay taxes. In most of the empirical studies, these variables turn out to have significant relation with tax morale. Montero and Torcal, (2006) defines political disaffection as the subjective feeling of powerlessness, cynicism, lack of confidence in the political process, in politicians and in democratic institutions. In this context, political disaffection is expected to have negative effect on tax morale. In addition, importance of politics and perception on democracy are important factors for explaining tax morale. People seem to be complying more in democratic countries, as they have the ability to affect tax and expenditure policies in these countries. National pride is another interesting factor that should be taken into account on the analyses about tax morale. When people are happy with their national identity, they would be more loyal to their countries, and therefore tax morale would be high. Religiosity is also affecting tax morale; indeed, positive relations between tax morale and religiosity have been found in some research. As Frank (1996) points out; tax compliance is more common among the people whose perception depends on moral and ethic codes. Religious people are so interested in what is right and what is wrong; therefore they believe that people have some duties to be performed: paying taxes is one of these duties.

The aim of this paper is to derive a comprehensive framework of the determinants of tax morale in two countries. As outlined here, various socio-economic factors are related to the concept of tax morale. It is thought that they affect tax morale in different degrees. The previous empirical studies prove the existence of these effects on tax morale; yet the way and the degree of impacts differentiate across the studies. In this paper, the effects of these socio-economic factors on tax morale are evaluated for Turkey and Spain individually; then the findings are compared to picture the differences and similarities for each country. There is much that Turkey and Spain have common. They share a number of historic similarities which coupled with contemporary considerations (Chislett, 2008). According to Chislett (2008), both of the countries are at opposite ends of the Mediterranean on the periphery of Europe, both have a long Islamic past, both have had large empires, both were significantly agricultural economies, both have undergone massive 
internal migration from rural areas to cities and towns, both have 'exported' hundreds of thousands of workers to elsewhere in Europe, both countries have had strong statist economic policies until their economies began to be opened up, both countries were enlisted for geostrategic reasons during the Cold War years by the US, both joined the Organisation for Economic Co-operation and Development (OECD) in 1961, both have problems in containing minority nationalisms, both Spain and Turkey have also suffered from real or imagined 'black legends' that even today affect the countries' images abroad. This paper searches whether the effects of the independent variables on tax morale differentiates between these similar countries.

The next section reviews the previous empirical literature about the determinants of tax morale. The third section is about the methodology and data; it gives essential information about the estimation method and defines the variable used in the estimation. The fourth section gives the estimation results; it starts with the descriptive statistics and ordered probit estimation results for the case of Spain. The statistics and estimated parameters are explained in details. The same results and the interpretations are also presented for the case of Turkey. Finally, concluding remarks relating to the estimated results and the comparison of the countries are outlined.

\section{Previous Empirical Literature}

Studies on tax morale can be evaluated in two categories. The studies in the first group have focused on only one country and have analysed regional discrepancies and changes in time (Torgler 2005; Martinez-Vazquez and Torgler 2009; Prieto et al 2006). A second group of studies have been conducted in a comprehensive perspective with more countries included (Torgler and Schneider 2006; Alm and Torgler 2006; Cummings et al 2006), while Torgler (2006) and Alm and Torgler (2006) have used a wider set of data with many countries. All studies on tax morale and its determinants used the international databases such as International Social Survey Programme (ISSP), World Values Survey (WVS), European Values Survey (EVS) and African Opinion Survey (Afrobarometer).

Alm and Torgler (2005) compared tax morale levels of USA with Spain by using 1990 and 1995 WVS data that concluded that tax morale level in USA is higher. An explanation of their result might be that "compliance" as a social norm is better in USA when compared in Spain. A further comparative study conducted by Alm and Torgler (2006) analysed tax morale in 14 European countries and the USA by using WVS data in 1990-1993; they still found that the highest tax morale is in the USA. In both of these articles, weighted ordered probit model was estimated to get the results.

Torgler and Schneider (2006) have a similar research analysing Spain, Switzerland and Belgium, by using the 1995-1997 WVS and 1999-2000 EVS data. They estimated a weighted ordered probit model in which the variables of gender, age, marital status, education, employment status, social class, income level, attendance at church, direct democracy, national pride, confidence in political institutions and government, participation in democracy, income tax rate, fine rate and probability of detection are used as independent variables. The regional discrepancies in Spain and Switzerland affect tax morale, females have higher tax morale than males. They concluded that confidence in justice system, confidence in government, confidence in parliament, national pride, attitudes supporting democracy have positive effect on tax morale.

Torgler (2006) looked at the determinants of tax morale in 32 countries (including Spain) by using the WVS data of 1995-1997. The included variables in the weighted ordered probit model are gender, age, marital status, education, employment status, social class, financial situation, risk averness, religiosity, corruption and credibility. The author found out that religiosity in particular for 
Catholics, Hindus, and Buddhists increases tax morale. Risk aversion and financial satisfaction positively affect tax morale. Tax morale is low for the high-class, and it is high for the retired, housewives, and the part-time employed. In addition, females and married people have high tax morale. On the contrary, there is a negative relation between education and tax morale; perception of level of corruption decreases tax morale.

Similar research was conducted by Cummings et al (2006) analysing Botswana and South Africa by using Afronarometer data of 1999 and 2000, by Gokbunar et al (2007) on Turkey by using EVS data of 2002, and by Martínez-Vázquez and Torgler (2009) on Spain by using WVS and EVS data of 1981, 1990, 1995 and 1999-2000. These scholars provided similar results about the determinants of tax morale, whose levels heavily depend on socio-demographic and social capital factors.

Kaynar-Bilgin (2011) searched for the determinants of tax morale in Turkey by using the WVS data of 2005-2008. The included variables for probit model are gender, age, marital status, education, employment status, income level, financial satisfaction, religiosity, national pride, confidence in government, justice system and parliament, importance of politics and religiosity. The author found out that religiosity, importance of religiosity, importance of politics, national pride, and confidence in government, all positively affect tax morale. Tax morale is low for the unemployed.

\section{Methodology and Data}

The methods used by the empirical studies are fairly similar since tax morale is a categorical variable. In general, ordered probit models were preferred for use in determining the relations and the interactions between tax morale and personal, socio-economic factors. Ordered probit models are very useful to analyse dependent variables of tax morale containing ordering information. Therefore, the same estimation method is used in this paper.

The magnitudes of estimation are not interpreted, only the signs are analysed because equation in ordered probit model is in the nonlinear form. Thus marginal effects should be derived to determine the effect of each variable on tax morale. Marginal effect indicates the probality of specific tax morale category when an independent variable increases by one unit. In practice, only marginal effects related to the top level of tax morale category have been evaluated.

For this paper, WVS database is used to analyse the level of tax morale and its determinants in Turkey and Spain. The fifth wave of the WVS is used for this aim. WVS is a survey which researched socio-cultural and political changes in a global base. The fourth and fifth waves have more than 50 countries representing approximately 80 percent of the world population. In this survey, individuals are asked to respond to the following question to evaluate level of tax morale:

Please tell me for the following statement whether you think it can always be justified, never be justified, or something in between: ... "'cheating on tax if you have the chance".

The question leads to a ten-scale index of tax morale with the two extreme points "never justified" and "always justified". The responses close to " 1 " can be thought as respectively high level of tax morale while the ones close to "10" indicate low level of tax morale. The ten-scale index of tax morale is transformed into four-scale index $(0,1,2,3)$ by the same method used in the related studies. In the transformed scale "0" implies "always justified" and " 3 " implies "never justified". The responses in the interval 4-10 in the original scale become "0" in the new scale since they imply that people justify tax cheating anyhow. Besides "never justified" option "1" in the original scale now is " 3 ".

The independent variables are classified as four categories: social capital variables; demographic factors; employment status; and economic status. 
Variables of social capital are importance of politics, importance of religion, confidence in the justice system, confidence in government, confidence in parliament, confidence in civil services, religiosity, national pride and education level. Since religiosity, national pride and education level are mostly defined as social capital variables in the empirical literature, they are evaluated as parts of the social capital group. Gender, age and marital status are among the demographic factors that are included in the model. For the employment status, we have full-time employed, part-time employed, retired, housewife, student, unemployed, employed in public sector, or employed in the private sector. Income level and financial satisfaction level are the indicators of economic status. The detailed definitions of the variables are presented in the Appendix.

\section{Estimation Results}

First of all, the descriptive statistics of all variables used in the model for Spain are derived. Table 1 shows these statistics. The percentage rates of persons having specific properties in the whole population are as follows; female 50 , married 58 , the $30-49$ age group 36 , the $50+$ age group 40 , the $16-29$ age group 24 . The percentage rates for education level are as follows: level 2 is 20 percent, level 3 is 16 percent, and level 4 is 8 percent. Of the respondents 3.9 percent are part-time employed, 7.7 percent are self-employed, 19 percent are retired, 17 percent are housewives, 7 percent are students, and 4.6 percent are unemployed.

When it comes to the variable of tax morale, 63 percent of the individuals have the highest tax morale level. These individuals respond that cheating on tax is never justified. The rates of the levels 3 and 2 are 10 percent and 6 percent respectively. The rate of people saying cheating is always justifiable is 19 percent. The rates of income levels are 34 percent for level 1, 43 percent for level 2, 21 percent for level 3,3 percent for level 4 . The rates of financial satisfaction for levels $1,2,3$ and 4 are $10,30,43$ and 17 percent respectively.

The variables of religiosity and national pride give the relatively high values of 44 and 92 percent. Besides 14 percent of them thinks that religion is important. The ratio of respondents considering politics is an important issue is relatively low, 7.7 percent. Other figures are as follows: confidence in justice system, 54 percent; confidence in government, 44 percent; confidence in parliament, 49 percent; and confidence in the civil service, 39 percent. Among the social capital variables, national pride has the highest figure with 92 percent of respondents proud of their national identity. Confidence in entities of the political system is relatively high from 39 to 54 percent. 
Table 1: Descriptive Statistics of the Variables for Spain

\begin{tabular}{|c|c|c|c|c|}
\hline Variables & Mean & Std. Deviation & Minimum & Maximum \\
\hline Tax Morale (level 1) & 0.195833 & 0.397006 & 0 & 1 \\
\hline Tax Morale (level 2) & 0.064416 & 0.245152 & 0 & 1 \\
\hline Tax Morale (level 3) & 0.102500 & 0.303431 & 0 & 1 \\
\hline Tax Morale (level 4) & 0.637500 & 0.480923 & 0 & 1 \\
\hline \multicolumn{5}{|c|}{ 1) Social Capital } \\
\hline Importance of Politics & 0.077500 & 0.267495 & 0 & 1 \\
\hline Importance of Religion & 0.147500 & 0.354751 & 0 & 1 \\
\hline Confidence in Justice System & 0.540000 & 0.498605 & 0 & 1 \\
\hline Confidence in Government & 0.440833 & 0.496694 & 0 & 1 \\
\hline Confidence in Parliament & 0.491667 & 0.500139 & 0 & 1 \\
\hline Confidence in Civil Services & 0.390000 & 0.487953 & 0 & 1 \\
\hline Religiosity & 0.440833 & 0.496694 & 0 & 1 \\
\hline National Pride & 0.920833 & 0.270111 & 0 & 1 \\
\hline Education (level 1) & 0.539167 & 0.498671 & 0 & 1 \\
\hline Education (level 2) & 0.206667 & 0.405083 & 0 & 1 \\
\hline Education (level 3) & 0.160833 & 0.367530 & 0 & 1 \\
\hline Education (level 4) & 0.076666 & 0.266173 & 0 & 1 \\
\hline \multicolumn{5}{|c|}{ 2) Demographic Factors } \\
\hline Gender (Male) & 0.500000 & 0.500208 & 0 & 1 \\
\hline Gender (Female) & 0.500000 & 0.500208 & 0 & 1 \\
\hline 16-29 Age Interval & 0.229167 & 0.420472 & 0 & 1 \\
\hline 30-49 Age Interval & 0.362500 & 0.480923 & 0 & 1 \\
\hline 50-98 Age Interval & 0.408333 & 0.491730 & 0 & 1 \\
\hline Marital Status (Unmarried) & 0.415000 & 0.492927 & 0 & 1 \\
\hline Marital Status (Married) & 0.585000 & 0.492927 & 0 & 1 \\
\hline \multicolumn{5}{|c|}{ 3) Employment Status } \\
\hline Full-time & 0.390000 & 0.487953 & 0 & 1 \\
\hline Part-time & 0.039166 & 0.194072 & 0 & 1 \\
\hline Self-employed & 0.077500 & 0.267495 & 0 & 1 \\
\hline Retired & 0.195833 & 0.397006 & 0 & 1 \\
\hline Housewife & 0.170833 & 0.376520 & 0 & 1 \\
\hline Student & 0.074166 & 0.262151 & 0 & 1 \\
\hline Unemployed & 0.046666 & 0.211012 & 0 & 1 \\
\hline Private & 0.565833 & 0.495854 & 0 & 1 \\
\hline \multicolumn{5}{|c|}{ 4) Economic Status } \\
\hline Income Level (level 1) & 0.254167 & 0.435573 & 0 & 1 \\
\hline Income Level (level 2) & 0.431668 & 0.495515 & 0 & 1 \\
\hline Income Level (level 3) & 0.211668 & 0.408660 & 0 & 1 \\
\hline Income Level (level 4) & 0.029167 & 0.168344 & 0 & 1 \\
\hline Financial Satisfaction (level 1) & 0.091667 & 0.288675 & 0 & 1 \\
\hline Financial Satisfaction (level 2) & 0.300833 & 0.458812 & 0 & 1 \\
\hline Financial Satisfaction (level 3) & 0.430833 & 0.495399 & 0 & 1 \\
\hline Financial Satisfaction (level 4) & 0.170000 & 0.375789 & 0 & 1 \\
\hline
\end{tabular}

Data Source: World Values Survey Database; http://www.worldvaluessurvey.org/ 
Table 2 gives the results of the estimated ordered probit model for Spain. In this estimation, the dependent variable is the tax morale variable as defined earlier. The independent variables are drawn from social capital, demography, employment status, and the economic situation. The second column indicates the estimated coefficient for each independent variable. The coefficients cannot be directly interpreted since the model is non-linear. Yet the signs of each coefficient can be evaluated. In the third and fourth columns, there are associated standard errors and z-statistics for each variable respectively. The statistical significances of the variables are determined by using the z-statistics. In the last column, the marginal effects of the independent variables on the dependent variable are given. These effects are the ones related to the top level of tax morale category $(Y=3)$. Moreover, the specification test statistics are given at the end; the estimated model seems to be statistically significant.

Most of the social capital variables, importance of politics, importance of religion, confidence in justice system, confidence in government, confidence in parliament, and confidence in the civil service, appear to be statistically insignificant and do not have effect on tax morale in this sample level. The estimated coefficients of the variables of national pride and education level 4 are statistically significant at the 1 percent level while the one of religiosity is significant at the 5 percent level; besides they are all positive. These findings imply that national pride and religiosity have positive effects on tax morale. Moreover, the most educated people have higher tax morale. The estimated coefficient of the highest level of education has the largest marginal effect among the significant social capital variables at 0.18

According to the estimated model, gender and marital status seem to have nothing to do with tax morale. Age interval coefficients, on the other hand, are fairly significant and their signs are positive implying that tax morale is higher for elderly persons. The marginal effect belonging to the variable of the 30-49 age group is 0.12 . Being in the highest education category increases the probability of being at the top level of tax morale by 0.12 units comparing to the lowest level of education. When it comes to employment status, the results are not remarkable - all of the variables in this category except students are not significant. Students have higher tax morale than full-time employees have.

Interestingly, respondents who are at the top level of income turn out to have lower tax morale than the lowest group. In addition to this, the financial satisfaction variable has a negative significant effect on tax morale. The highest level of this category has a statistically significant estimated coefficient. 
Table 2: Ordered Probit Model Estimation for Spain

\begin{tabular}{|c|c|c|c|c|}
\hline Independent Variables & Coefficient & $\begin{array}{l}\text { Standard } \\
\text { Error }\end{array}$ & z-value & $\begin{array}{l}\text { Marginal } \\
\text { Effects }\end{array}$ \\
\hline \multicolumn{5}{|l|}{ 1) Social Capital } \\
\hline \multicolumn{5}{|l|}{ Importance of Politics } \\
\hline \multicolumn{5}{|l|}{ Importance of Religion } \\
\hline Confidence in Justice & $\begin{aligned}-0.193061 \\
0.176889\end{aligned}$ & & & \\
\hline \multirow{2}{*}{\multicolumn{4}{|c|}{$\begin{array}{c}\text { System } \\
\text { Confidence in Government }\end{array}$}} & \\
\hline & $\begin{array}{l}0.058499 \\
-0.051011\end{array}$ & 0.135398 & -1.426 & -0.0739 \\
\hline Confidence in Parliament & -0.020400 & 0.115744 & 1.528 & 0.0644 \\
\hline Confidence in Civil Service & 0.076616 & 0.079132 & 0.739 & 0.0219 \\
\hline Religiosity & $0.135098^{*}$ & 0.084690 & -0.602 & -0.0191 \\
\hline National Pride & $0.379701^{* * *}$ & 0.087950 & -0.232 & -0.0076 \\
\hline Education (level 2) & 0.060485 & 0.081206 & 0.943 & 0.0285 \\
\hline Education (level 3) & 0.150077 & 0.080430 & 1.680 & 0.0503 \\
\hline Education (level 4) & $0.552271^{* * *}$ & 0.133833 & 2.837 & 0.1475 \\
\hline 2) Demographic Factors & & 0.104411 & 0.579 & 0.0224 \\
\hline Female & -0.088738 & 0.120894 & 1.241 & 0.0549 \\
\hline \multicolumn{4}{|l|}{ 30-49 Age Interval } & 0.1828 \\
\hline \multicolumn{5}{|l|}{ 50-98 Age Interval } \\
\hline 3) Employment Status & 0.039771 & 0.082358 & & -0.0331 \\
\hline Part-time & & 0.112433 & $\begin{array}{l}3.111 \\
2213\end{array}$ & 0.1276 \\
\hline $\begin{array}{l}\text { Part-tıme } \\
\text { Self-employed }\end{array}$ & 0.151088 & 0.133045 & & 0.1085 \\
\hline Retired & -0.229823 & 0.087424 & 0.455 & 0.0149 \\
\hline \multirow{2}{*}{$\begin{array}{l}\text { Housewife } \\
\text { Student }\end{array}$} & 0.137709 & & 0775 & \\
\hline & 0.181493 & 0.194842 & $0.1 / 5$ & 0.0548 \\
\hline Unemployed & $0.418436^{* *}$ & 0.156199 & $-1.4 / 1$ & -0.0883 \\
\hline & 0.246105 & 0.131056 & $\begin{array}{l}1.051 \\
1.307\end{array}$ & 0.0506 \\
\hline \multirow{2}{*}{ 4) Economic Status } & 0.111949 & 0.138894 & $\begin{array}{l}1.301 \\
2381\end{array}$ & 0.0661 \\
\hline & & 0.175769 & & 0.1434 \\
\hline Income Level (level 2) & 0.007230 & 0.190259 & $\begin{array}{l}1.294 \\
1225\end{array}$ & 0.0875 \\
\hline $\begin{array}{l}\text { Income Level (level 3) } \\
\text { Income Level (level 4) }\end{array}$ & -0.043904 & 0.091400 & & 0.0419 \\
\hline \multirow{2}{*}{$\begin{array}{l}\text { Financial Satisfaction (level } \\
2 \text { ) }\end{array}$} & $-0.399906^{*}$ & & 0080 & \\
\hline & -0.171399 & 0.090271 & $\begin{array}{r}0.080 \\
-0.393\end{array}$ & 0.0027 \\
\hline \multirow{2}{*}{$\begin{array}{c}\text { Financial Satisfaction (level } \\
3 \text { ) }\end{array}$} & -0.191946 & 0.111705 & $\begin{array}{l}-0.393 \\
-1.727\end{array}$ & -0.0165 \\
\hline & $-0.328749^{* *}$ & 0.231603 & $\begin{array}{l}-1 . / 21 \\
-1.213\end{array}$ & -0.1561 \\
\hline \multirow{2}{*}{ Financial Satisfaction (level } & & 0.141282 & -1369 & -0.0647 \\
\hline & 1200 & 0.140196 & -1.369 & -0.0719 \\
\hline 4) & 0.000000 & 0.157227 & -2.091 & -0.1264 \\
\hline \multirow{4}{*}{$\begin{array}{c}\text { Number of Observations } \\
\text { Prob (ChiSqd>value) } \\
\text { Information Criterion (AIC) } \\
\text { Pseudo R2 }\end{array}$} & 2.02991 & & & \\
\hline & 0.026466 & & & \\
\hline & & & & \\
\hline & & & & \\
\hline
\end{tabular}

Notes: Dependent variable is tax morale on a four-point scale (0 to 3). The reference groups: the $16-29$ age interval for the age variable, males, unmarried for marital status, full-time employed for employment status, public sector for the institution of occupation, education level 1 for education, income level 1 for income, financial satisfaction level 1 for the financial satisfaction variable. ${ }^{*},{ }^{* *}$ and ${ }^{* * *}$ refer to statistically significant parameter estimates at the 10,5 and 1 percent levels respectively.

Data Source: World Values Survey Database; http://www.worldvaluessurvey.org/

Table 3 shows descriptive statistics of the variables for the case of Turkey. Of the respondents 49 percent are female, 66 percent are married, 41 percent are in the 30-49 age interval, 17 percent are in the 50+ age interval and 42 percent are in the 16-29 age interval. Rates of education level 1, 2, 3 and 4 are 52, 10, 27 and 11 percent respectively. The shares of the full-time, part-time and self-employed persons in all are 30, 2 and 13 percent respectively. The figures for the retired, students and the unemployed are 9, 8 and 6 percent. Religiosity and national pride figures are relatively high at 80 and 89 percent. Confidence in the entities of political system is lower compared to that in Spain. Income level rates indicate that the largest part of the population is in the lowest income level. 74 percent of the respondents think religion is important and 13 percent of them think politics is important in their life. When it comes to tax morale level, level 4 gives the highest rate which is that 80 percent of respondents find that cheating on taxes is never justifiable. Besides, only 3 percent of them say that it is always justifiable. 
The ordered probit model is indicated by Table 4 . The dependent variable is the tax morale level, the independent variables are related to social capital, demographic factors, employment status and the economic situation. The model is statistically significant since the probability value of chi-square is much less than 0.01 .

The important part of the social capital variables appear to be statistically significant. Importance of politics, importance of religion, religiosity, and national pride are all statistically significant at the 1 percent level. The estimated coefficients for the variables of confidence in government and confidence in the justice system are significant at the 5 and 10 percent levels.

Marginal effect of confidence in justice system on tax morale is 0.04 and is positive. Those trusting the justice system have high tax morale. The same applies to confidence in government, which implies higher tax morale. Taxpayers' confidence in government means that they approve government's taxation policies and its related decisions. The marginal effects of the importance of religion and religiosity are 0.12 and 0.08 respectively. In this case, it might be said that religion affects tax morale positively. As an explanation of this, religion extensively covers the beliefs about the right behaviour. According to Hull (2000) religion has the ability to prevent illegal behaviours since it legitimises and reinforces social values. Paying taxes is seen as a social norm and it is motivated by religion. The marginal effect of national pride is 0.13 , so it is positive and among the largest marginal effects. It is clear that national pride supports tax morale. When people are satisfied with their national identities, they are usually devoted to their states and governments.

None of the demographic factors are statistically significant. Among the employment status factors, only unemployed and private sector have effect on tax morale. While the unemployed persons have less tax morale, private sector employees have higher tax morale than public sector employees. When it comes to the category of economic status, none of these factors can be evaluated as determinants of tax morale since the related estimations are not statistically significant at any level.

The estimated model points out that the most effective factors on tax morale in Turkey are the factors of social capital. When compared with the individualistic variables, the variables related to social capital have stronger relations with tax morale. The feelings of confidence, religiosity and national pride seem to be very important to understand the concept of tax morale in Turkey. In other words what persons feel about themselves and how much they trust social entities are strongly related the level of tax morale. 
Table 3: Descriptive Statistics of the Variables for Turkey

\begin{tabular}{|c|c|c|c|c|}
\hline Variables & Mean & Std.Deviation & Minimum & Maximum \\
\hline Tax Morale (level 1) & 0.034201 & 0.181812 & 0 & 1 \\
\hline Tax Morale (level 2) & 0.037175 & 0.189260 & 0 & 1 \\
\hline Tax Morale (level 3) & 0.119703 & 0.324734 & 0 & 1 \\
\hline Tax Morale (level 4) & 0.809822 & 0.393297 & 0 & 1 \\
\hline \multicolumn{5}{|c|}{ 1) Social Capital } \\
\hline Importance of Politics & 0.131599 & 0.338180 & 0 & 1 \\
\hline Importance of Religion & 0.748699 & 0.433923 & 0 & 1 \\
\hline Confidence in Justice System & 0.353903 & 0.478358 & 0 & 1 \\
\hline Confidence in Government & 0.260967 & 0.439325 & 0 & 1 \\
\hline Confidence in Parliament & 0.203717 & 0.402911 & 0 & 1 \\
\hline Confidence in Civil Service & 0.099628 & 0.299615 & 0 & 1 \\
\hline Religiosity & 0.805204 & 0.396191 & 0 & 1 \\
\hline National Pride & 0.899628 & 0.300607 & 0 & 1 \\
\hline Education (level 1) & 0.504089 & 0.500169 & 0 & 1 \\
\hline Education (level 2) & 0.105576 & 0.307409 & 0 & 1 \\
\hline Education (level 3) & 0.278811 & 0.448581 & 0 & 1 \\
\hline Education (level 4) & 0.111524 & 0.314897 & 0 & 1 \\
\hline \multicolumn{5}{|c|}{ 2)Demographic Factors } \\
\hline Gender (Male) & 0.501859 & 0.500183 & 0 & 1 \\
\hline Gender (Female) & 0.498141 & 0.500183 & 0 & 1 \\
\hline 16-29 Age Interval & 0.402974 & 0.490678 & 0 & 1 \\
\hline 30-49 Age Interval & 0.418587 & 0.493511 & 0 & 1 \\
\hline 50-98 Age Interval & 0.178439 & 0.383024 & 0 & 1 \\
\hline Marital Status (Unmarried) & 0.337546 & 0.473049 & 0 & 1 \\
\hline Marital Status (Married) & 0.662454 & 0.473049 & 0 & 1 \\
\hline \multicolumn{5}{|c|}{ 3) Employment Status } \\
\hline Full-time & 0.228996 & 0.420343 & 0 & 1 \\
\hline Part-time & 0.027509 & 0.163623 & 0 & 1 \\
\hline Self-employed & 0.133829 & 0.340595 & 0 & 1 \\
\hline Retired & 0.094423 & 0.292526 & 0 & 1 \\
\hline Housewife & 0.343494 & 0.475051 & 0 & 1 \\
\hline Student & 0.088475 & 0.284091 & 0 & 1 \\
\hline Unemployed & 0.060964 & 0.239358 & 0 & 1 \\
\hline Private & 0.446840 & 0.497351 & 0 & 1 \\
\hline \multicolumn{5}{|c|}{ 4) Economic Status } \\
\hline Income Level (level 1) & 0.609665 & 0.488007 & 0 & 1 \\
\hline Income Level (level 2) & 0.180669 & 0.384887 & 0 & 1 \\
\hline Income Level (level 3) & 0.088478 & 0.284091 & 0 & 1 \\
\hline Income Level (level 4) & 0.101118 & 0.301593 & 0 & 1 \\
\hline Financial Satisfaction (level 1) & 0.129368 & 0.335732 & 0 & 1 \\
\hline Financial Satisfaction (level 2) & 0.231226 & 0.421774 & 0 & 1 \\
\hline Financial Satisfaction (level 3) & 0.406691 & 0.491399 & 0 & 1 \\
\hline Financial Satisfaction (level 4) & 0.228995 & 0.420343 & 0 & 1 \\
\hline
\end{tabular}

Data Source: World Values Survey Database; http://www.worldvaluessurvey.org/ 
Table 4: Ordered Probit Model Estimation for Turkey

\begin{tabular}{|c|c|c|c|c|}
\hline Independent Variables & Coefficient & $\begin{array}{c}\text { Standard } \\
\text { Error }\end{array}$ & z-value & $\begin{array}{c}\text { Marginal } \\
\text { Effects }\end{array}$ \\
\hline \multicolumn{5}{|l|}{ 1) Social Capital } \\
\hline Importance of Politics & \multicolumn{4}{|l|}{$0.369703^{* * *}$} \\
\hline Importance of Religion & \multicolumn{4}{|l|}{$0.435832^{* \star *}$} \\
\hline \multicolumn{5}{|l|}{ Confidence in Justice System } \\
\hline Confidence in Government & $0.296404^{* *}$ & $\begin{array}{l}0.133793 \\
0.097435\end{array}$ & $\begin{array}{l}2.763 \\
4.473\end{array}$ & $\begin{array}{l}0.0815 \\
0.1213\end{array}$ \\
\hline Confidence in Parliament & -0.022028 & $\begin{array}{l}0.09 / 435 \\
0.105660\end{array}$ & $\begin{array}{l}4.470 \\
1.669\end{array}$ & 0.0435 \\
\hline Confidence in Civil Service & \multirow{2}{*}{$\begin{array}{c}-0.059884 \\
0.299047^{* * *}\end{array}$} & $\begin{array}{l}0.105660 \\
0.125291\end{array}$ & & 0.0699 \\
\hline Religiosity & & $\begin{array}{l}0.125291 \\
0.134359\end{array}$ & $\begin{array}{r}2.366 \\
-0.164\end{array}$ & $\begin{array}{r}0.0699 \\
-0.0056\end{array}$ \\
\hline National Pride & $0.447546^{* * *}$ & & & \\
\hline Education (level 2) & \multirow[t]{2}{*}{0.040732} & 0.161653 & $\begin{array}{r}-0.370 \\
2.839\end{array}$ & -0.0155 \\
\hline Education (level 3) & & 0.105325 & 2.839 & 0.0821 \\
\hline Education (level 4) & $\begin{array}{l}0.068301 \\
0.271146\end{array}$ & 0.125907 & 3.555 & 0.1318 \\
\hline 2) Demographic Factors & \multirow[b]{2}{*}{0.045841} & 0.142562 & 0.286 & 0.0101 \\
\hline Female & & 0.118135 & 0.578 & 0.0170 \\
\hline 30-49 Age Interval & \multicolumn{4}{|l|}{-0.041882} \\
\hline 50-98 Age Interval & \multirow{2}{*}{$\begin{array}{l}0.038892 \\
0.114222\end{array}$} & & & \\
\hline Married & & 0.123619 & $\begin{array}{l}0.371 \\
0394\end{array}$ & 0.0116 \\
\hline 3) Employment Status & 0.114222 & $\begin{array}{l}0.106269 \\
0.157216\end{array}$ & $\begin{array}{l}-0.394 \\
0.247\end{array}$ & $\begin{array}{l}-0.0106 \\
0.0097\end{array}$ \\
\hline Part-time & -0.124043 & 0.110406 & 1.035 & 0.0294 \\
\hline Self-employed & \multicolumn{4}{|l|}{-0.087781} \\
\hline Retired & \multirow{2}{*}{0.040662} & 0.242470 & -0.512 & -0.0331 \\
\hline Housewife & & 0.142623 & -0.615 & -0.0229 \\
\hline Student & 0.123917 & 0.190237 & 0.214 & 0.0101 \\
\hline Unemployed & $-0.417013^{* *}$ & 0.166322 & -0.728 & -0.0312 \\
\hline Private Sector & \multirow[t]{2}{*}{$0.186067^{*}$} & $\begin{array}{l}0.166322 \\
0.182094\end{array}$ & 0.681 & 0.0298 \\
\hline 4) Economic Status & & 0.171534 & -2.431 & -0.1232 \\
\hline $\begin{array}{l}\text { Income Level (level 2) } \\
\text { Income Level (level 3) }\end{array}$ & -0.163385 & 0.109411 & 1.701 & 0.0466 \\
\hline $\begin{array}{l}\text { Income Level (level 3) } \\
\text { Income Level (level 4) }\end{array}$ & 0.083103 & & & \\
\hline Financial Satisfaction (level 2) & \multirow{2}{*}{0.131735} & 0.108557 & -1.505 & -0.0434 \\
\hline Financial Satisfaction (level 3) & & 0.150657 & -0.506 & -0.0199 \\
\hline Financial Satisfaction (level 4) & \multirow{2}{*}{0.008572} & 0.158473 & 0.524 & 0.0204 \\
\hline & & 0.140117 & 0.940 & 0.0322 \\
\hline Number of Observations & \multirow{4}{*}{$\begin{array}{c}1345 \\
0.0000000 \\
1.27499 \\
0.073878\end{array}$} & 0.131878 & -0.017 & -0.0006 \\
\hline Prob (ChiSqd>value) & & 0.143839 & 0.060 & 0.0022 \\
\hline Information Criterion (AIC) & & & & \\
\hline Pseudo R2 & & & & \\
\hline
\end{tabular}

Notes: Dependent variable is tax morale on a four-point scale (0 to 3). The reference groups: $16-29$ age interval for the age variable, males, unmarried for marital status, full-time employed for employment status, public sector for the institution of occupation, education level 1 for education, income level 1 for income, financial satisfaction level 1 for the financial satisfaction variable. * ${ }^{* *}$ and ${ }^{* * *}$ refer statistically significant parameter estimates at the 10,5 and 1 percent levels respectively.

Data Source: World Values Survey Database; http://www.worldvaluessurvey.org/

Comparing these findings with the ones derived from Spain's model indicates that the determinants of tax morale in the two countries are not so similar. Contrary to Turkey case, confidence in political entities does not explain tax morale in Spain. Religion does not have such an important role as in Turkey. Under the social capital title, only national pride and education level 4 have a real effect on tax morale. Tax morale in Spain is more related to the individualistic factors while it is a social confidence phenomenon in Turkey. Age, education, income level and financial satisfaction are significant in Spain.

\section{Conclusion}

The determinants of tax morale were analysed by estimating ordered probit models for Spain and Turkey. For this aim, we estimated two models for each country. In the first model for Spain, the variables of religiosity, national pride, education level 4, 30-49 age interval, 50+ age interval, student, income level 4, and financial satisfaction level 4 were found to be statistically significant at different significance levels. That is, all these variables have effects on tax morale in different degrees. In Spain, mostly individualistic factors are explaining tax morale. As social capital 
variables, only national pride and one part of the education level have strong effects on tax morale. Religiosity is significant at only the 10 percent level.

The second model for Turkey indicates that the variables of the importance of religion, importance of politics, confidence in the justice system, confidence in government, religiosity, national pride, unemployment, or private sector employment are statistically significant. The perceptions of religion and politics, confidence in the justice system, confidence in government, being religious, having national pride, and working for the private sector have positive effects on tax morale. The unemployed have lower tax morale.

The findings in this paper suggest that the determinants tax morale in Spain and Turkey seem to be different. In other words, the first and second models give different results that suggest the different structures of tax morale in Spain and Turkey. The estimations based on the WVS data for Spain and Turkey indicates that tax morale in Turkey can be seen as a social phenomenon where social capital variables have positive effects. Personal factors such as gender, age, being selfemployed or retired, income level and financial satisfaction seem to be irrelevant. On the contrary, age, income level, financial satisfaction and education level have significant effects on tax morale in Spain. It can be said that tax morale in Spain is highly related to individualistic conditions when compared to Turkey.

From this point of view, increasing institutional credibility as a public policy might raise the level of tax morale in Turkey leading to more tax compliance by taxpayers. On the other hand, the willingness of paying tax has nothing to do with the public institutional structure in Spain. It should be found that the ways to increase the level of tax morale of the wealthy taxpayers by raising their perception of having benefited from public goods and services might give improving results. Besides, increasing the general level of education and making younger people conscious of the benefits of public goods and services might increase the level of tax morale in Spain.

\section{References}

Alm, James and Benno Torgler (2005) 'Estimating the Determinants of Tax Morale', National Tax Association Papers and Proceedings, Minneapolis, pp. 269274.

Alm, James and Benno Torgler (2006) 'Culture Differences and Tax Morale in the United States and Europe', Journal of Economic Psychology, 27(2): 224-246.

Chislett, William (2008) Spanish Trajectory: A Source of Inspiration for Turkey, Open Society Institute: Istanbul.

Cummings, Ronald G., Jorge Martinez-Vazquez, Michael McKee and Benno Torgler (2006) 'Effects of Tax Morale on Tax Compliance: Experimental and Survey Evidence', Berkeley Program in Law and Economics Working Paper Series.

Duch, Raymond M., Harvey D. Palmer and Christopher J. Anderson (2000) 'Heterogeneity in Perceptions of National Economic Conditions', American Journal of Political Science, 44(4): 635-652 .

Feld, Lars P. and Bruno S. Frey (2002) 'Trust Breeds Trust: How Taxpayers Are Treated', Economics of Govarnance, 3(3): 87-99.

Frank, Robert H. (1996) 'What Price the Morale High Ground?', Southern Economic Journal, 63(1): 1-17.

Gökbunar, Ali R., Sibel Selim and Halit Yanıkkaya (2007) 'Türkiye'de Vergi Ahlakını Belirleyen Faktörler Üzerine Bir Araştırma', Ekonomik Yaklaşım, 18(63): 69-94 .

Hull, Brooks B. (2000) 'Religion Still Matters', The Journal of Economics, 26(2): 3548. 
Kaynar-Bilgin, Handan (2011) 'Türkiye'de Vergi Ahlakının Belirleyicileri', Odtü Gelişme, 38(2):167-190.

Martinez-Vazquez, Jorge and Benno Torgler (2009) 'The Evolution of Tax Morale in Modern Spain', Journal of Economic Issues, 43(1): 1-26.

Montero, Jose R. and Mariano Torcal (2006) 'Political Disaffection in Comparative Perspective', in Torcal, Mariano and José Ramón Montero (eds) Political Disaffection in Contemporary Democracies: Social Capital, Institutions, and Politics. London: Routledge

Prieto, Juan.; María J. Sanzo, and Javier Suárez-Pandiello (2006) 'Análisis económico de la actitud hacia el fraude fiscal en España', Hacienda Pública Española, 177:107-128.

Schmölders, Günter (1976) Genel Vergi Teorisi, İstanbul: Fakülteler Matbaası.

Torgler, Benno (2004) 'Tax Morale in Asian Countries', Journal of Asian Economics, 15(2): 237-266.

Torgler, Benno (2005) 'Tax Morale and Direct Democracy', European Journal of Political Economy, 21(2): 525-531.

Torgler, Benno (2006) 'The Importance of Faith: Tax Morale and Religiosity', Journal of Economic Behavior \& Organization, 61(1): 81-109.

Torgler, Benno (2007) Tax Compliance and Tax Morale: A Theoretical and Empirical Analysis, Cheltenham: Edward Elgar.

Torgler, Benno and Friedrich Schneider (2006) 'What Shapes Attitudes toward Paying Taxes? Evidence from Multicultural European Countries', Berkeley Program in Law \& Economics, Working Paper Series, No. 190. 


\section{Appendix}

Definition of Variables

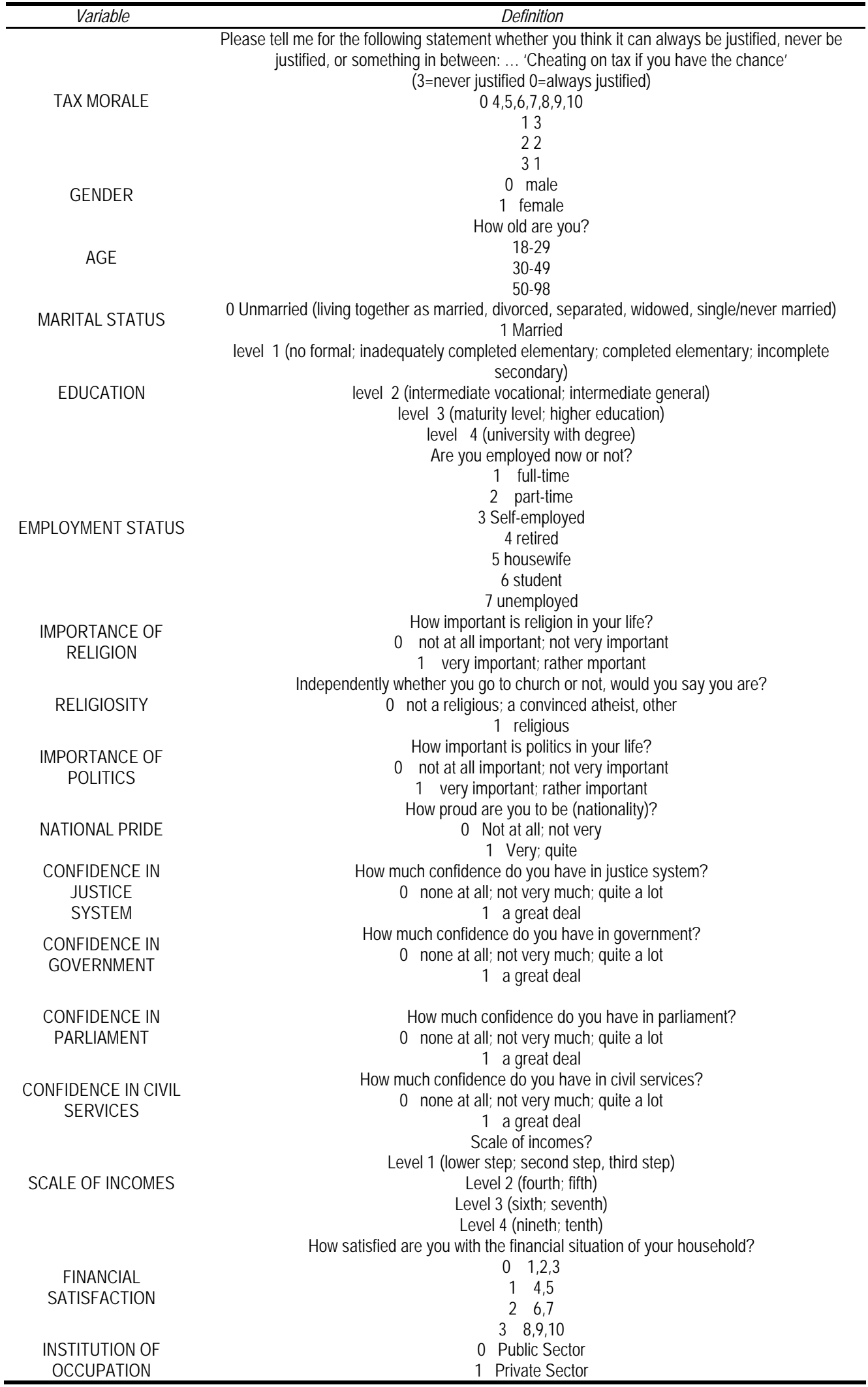

